\title{
Effect of Phosphorus, Sulphur and Zinc on Growth, Yield and Yield Attributes of Wheat (Triticum aestivum)
}

\section{Sandeep Kumar Yadav*, Ghanshyam Singh, Rajeev Kumar, Pradeep Kumar and Brij Mohan}

\author{
Department of Agronomy, N D University of Agriculture and Technology, \\ Faizabad 224 229, U.P., India \\ *Corresponding author
}

A B S T R A C T

Keywords

Wheat, Phosphorus, Sulphur. Zinc.

Article Info

Accepted:

21 June 2017

Available Online:

10 August 2017
A field experiment was conducted during the Rabi season 2012-2013and 2013-2014 at Agronomy Research Farm of NDUAT, Faizabad, to study the effect of phosphorus, sulphur and zinc on wheat (Tralcum aestivum L) Pooled data revealed that the growth parameters, yield attributes and yield increased significantly with application of $50 \mathrm{~kg} \mathrm{P}_{2} \mathrm{O}_{5}, 20 \mathrm{~kg} \mathrm{~S}$ and $10 \mathrm{~kg}$ $\mathrm{Zn} \mathrm{ha}{ }^{-1}$.

\section{Introduction}

Wheat is one of the most important cereal crops of India with diverse uses. Intensive cultivation has resulted in depletion of soil nutrients to a great extent thus nutrients requirement of crops has increased considerably during the last few years. Phosphorus is the backbone of any fertilizer management programme and plays key role in energy related activities and development of root system. Sulphur performs many physiological functions like synthesis of sulphur containing amino acids which have positive role in improving quality of grain. The soil of U.P. is deficient in micronutrient such as zinc, sulphur and boron. The application of $\mathrm{N}, \mathrm{P}, \mathrm{K}, \mathrm{S}$, and $\mathrm{Zn}$ containing fertilizer in proper proportion is necessary to augment the productivity of wheat. Hence, the effect of various nutrients in balanced proportion on yield of wheat will be of immense significance to understand the nutrients requirement because crops reach their full yield potential with adequate supply of various nutrients. Zinc is also an important micronutrient reported deficient in Indian soils and plays a significant role in various enzymatic and physiological activities of plant body. It helps in formation of chlorophyll and auxins. The present investigation was therefore conducted to find out efficient and balanced use of fertilizers for sustainable crop production in wheat.

\section{Materials and Methods}

The investigation was carried out during the winter (rabi) season of 2012-13 and 2013-14 at Kumarganj, Faizabad. The soil was silt 
loam with $8.15 \mathrm{pH} 0.43$ organic carbon, 0.32 EC, available $\mathrm{N}(137.0$ and $196.0 \mathrm{~kg} / \mathrm{ha}) . \mathrm{P}$ (19.0 and $21.0 \mathrm{~kg} / \mathrm{ha}), \mathrm{S}(6.50$ and 6.52 $\mathrm{kg} / \mathrm{ha}), \mathrm{Zn}(0.54$ and $0.57 \mathrm{ppm})$ and medium in $\mathrm{K}(251.0$ and $241.0 \mathrm{~kg} / \mathrm{ha})$. The experiment was laid out in split-plot design with 3 replications. Main plots were fertilized with 3 levels of phosphorus $\left(25,50\right.$ and $75 \mathrm{~kg} \mathrm{P}_{2} \mathrm{O}_{5}$ $\mathrm{ha}^{-1}$ ) and Subplots were fertilized with 3 levels of sulphur $(0,20$ and $40 \mathrm{~kg} \mathrm{~S} / \mathrm{ha})$ and 2 levels of zinc $(0$, and $10 \mathrm{~kg} \mathrm{Zn} / \mathrm{ha})$. Wheat variety 'HUW-234' was sown on 20 December 2012 during the first year and 23 December 2013 during the second year using a seed rate of $125 \mathrm{~kg} / \mathrm{ha}$ at a row spacing of $20.0 \mathrm{~cm}$. A common dose of $120 \mathrm{~kg} \mathrm{~N} / \mathrm{ha}$ was applied in 3 splits (half basal, one-fourth first and one- fourth at second irrigation). Sulphur was applied through elemental sulphur, phosphorus as diammonium phosphate and zinc applied through zinc oxide basal placed as per treatments.

\section{Results and Discussion}

Growth characters Pooled data (Table 1) revealed that application of $50 \mathrm{~kg} \mathrm{P}_{2} \mathrm{O}_{5} / \mathrm{ha}$ significantly increased the plant height, dry matter accumulation and total shoots which was significantly superior over $25 \mathrm{~kg} \mathrm{P}_{2} \mathrm{O}_{5} /$ ha application but remained at par with $75 \mathrm{~kg}$ $\mathrm{P}_{2} \mathrm{O}_{5} /$ ha. This may be attributed to better proliferation of roots and increased uptake of nutrients. The finding confirms the results of Karimi et al., (2015) and Noonari et al., (2016).

Application of $20 \mathrm{~kg}$ S/ha significantly increased the plant height, dry matter accumulation and total shoots over no application. Further increase in level of $\mathrm{S}$ at $40 \mathrm{~kg} / \mathrm{ha}$ could not bring significant improvement in these parameters. The greater photosynthetic activity and chlorophyll synthesis due to sulphur fertilization seemed to have promoted vegetative growth. Similar result was reported by Chaudhary et al., (2003) and Hrivna et al., (2015)

Zinc fertilization at $10 \mathrm{~kg} / \mathrm{ha}$ significantly enhanced all these growth parameters over the control. Zinc plays a pivotal role in regulating the auxin concentration in plant and nitrogen metabolism and might have improved these growth attributes. Singh et al., (1996) and Choudhary et al., (1997) also recorded significantly higher shoots/m row length and dry matter production of wheat over control.

\section{Yield attributes and yield}

Phosphorus fertilization at $50 \mathrm{~kg} \quad \mathrm{P}_{2} \mathrm{O}_{5} / \mathrm{ha}$ significantly increased effective shoots/m row length, grains/spike, spike length, test weight and grain, straw and biological yields of wheat over $25 \mathrm{~kg}$. This could be attributed to the fact that phosphorus plays a key role in root development, energy transformation and metabolic processes in plant Brady (1986) also observed beneficial effect of phosphorus on the fruiting of plants and ascribed the beneficial effect to better translocation of desired metabolites to the yield contributing parts of the plant. These results' are in confirmity with those of Mumtaz et al., (2014) and Noonari et al., (2016).

Successive increase in sulphur levels up to 20 $\mathrm{kg} / \mathrm{ha}$ significantly improved effective shoots, grains/spike, spike length and seed, straw and biological yields. The increase beyond $20 \mathrm{~kg}$ S/ha was non-significant. Since available sulphur status of the experimental fields was medium $(6.50$ and $6.52 \mathrm{~kg} / \mathrm{ha} \quad \mathrm{S}) . \mathrm{S}$ application improved nutritional environment of rhizosphere as well as plant system as evident from greater uptake of nutrients (Table 2) and ultimately metabolic and photosynthetic activity, resulting in better development of yield attributes and yield. Similar result were reported by Dwivedi et al., (2014) and Inamullah (2014). 
Table.1 Effect of phosphorus, sulphur and zinc on growth parameter, yield attributes and yield of wheat

\begin{tabular}{|c|c|c|c|c|c|c|c|c|c|c|}
\hline Treatment & $\begin{array}{c}\text { Plant } \\
\text { height }\end{array}$ & $\begin{array}{l}\text { Dry matter } \\
\text { accumulation } \\
\text { (g) per running } \\
\text { meter }\end{array}$ & $\begin{array}{l}\text { Number of } \\
\text { effective } \\
\text { shoots (m }{ }^{-1} \\
\text { row length) }\end{array}$ & $\begin{array}{c}\text { Spike } \\
\text { length } \\
\text { (cm) }\end{array}$ & $\begin{array}{c}\text { Number } \\
\text { of } \\
\text { spikelets } \\
\text { spike }^{-1}\end{array}$ & \begin{tabular}{|c} 
Number \\
of grains \\
spike $^{-1}$
\end{tabular} & $\begin{array}{c}\text { 1000- } \\
\text { grain } \\
\text { weight(g) }\end{array}$ & $\begin{array}{l}\text { Grain } \\
\text { yield } \\
\text { (q/ha) }\end{array}$ & $\begin{array}{l}\text { Straw } \\
\text { yield } \\
\text { (q/ha) }\end{array}$ & $\begin{array}{l}\text { Biological } \\
\text { yield (q/ha) }\end{array}$ \\
\hline \multicolumn{11}{|c|}{ Phosphorus levels $\left(\mathrm{P}_{2} \mathrm{O}_{5} \mathrm{~kg} \mathrm{ha}^{-1}\right)$} \\
\hline $\mathbf{P}_{25}$ & 77.22 & 152.83 & 57.04 & 7.73 & 19.85 & 36.43 & 31.78 & 30.56 & 42.05 & 72.60 \\
\hline $\mathbf{P}_{50}$ & 83.76 & 165.73 & 71.48 & 8.93 & 23.05 & 42.16 & 33.30 & 35.71 & 47.73 & 83.43 \\
\hline $\mathbf{P}_{75}$ & 87.15 & 172.47 & 74.56 & 9.17 & 23.74 & 43.53 & 33.93 & 36.73 & 49.48 & 86.21 \\
\hline SEm \pm & 1.42 & 3.83 & 1.38 & 0.17 & 0.48 & 0.82 & 0.63 & 0.65 & 1.01 & 1.67 \\
\hline $\mathrm{CD}$ at $5 \%$ & 5.59 & 14.35 & 5.42 & 0.68 & 1.87 & 3.22 & NS & 1.90 & 3.97 & 6.56 \\
\hline \multicolumn{11}{|c|}{ Sulphur level $\left(\mathrm{kg} \mathrm{ha}^{-1}\right)$} \\
\hline $\mathbf{S}_{\mathbf{0}}$ & 78.37 & 152.92 & 59.67 & 7.89 & 20.43 & 37.48 & 32.24 & 31.59 & 42.95 & 74.54 \\
\hline $\mathbf{S}_{20}$ & 83.965 & 166.89 & 70.97 & 8.79 & 22.68 & 41.95 & 33.10 & 35.08 & 47.52 & 82.59 \\
\hline $\mathbf{S}_{40}$ & 85.8 & 171.22 & 72.43 & 9.08 & 23.52 & 42.83 & 33.66 & 36.33 & 48.80 & 85.12 \\
\hline SEm \pm & 1.28 & 2.32 & 1.00 & 0.16 & 0.31 & 0.78 & 0.60 & 0.65 & 0.67 & 1.57 \\
\hline $\mathrm{CD}$ at $5 \%$ & 3.7 & 6.71 & 2.89 & 0.46 & 0.90 & 2.24 & NS & 31.59 & 1.94 & 4.53 \\
\hline \multicolumn{11}{|c|}{ Zinc levels $\left(\mathrm{kg} \mathrm{ha}^{-1}\right)$} \\
\hline $\mathbf{Z n}_{\mathbf{0}}$ & 80.28 & 160.86 & 65.83 & 8.36 & 21.81 & 39.67 & 32.56 & 33.41 & 45.55 & 78.96 \\
\hline $\mathbf{Z n} 10$ & 85.14 & 166.49 & 69.56 & 8.82 & 22.62 & 41.84 & 33.45 & 35.25 & 47.28 & 82.53 \\
\hline SEm \pm & 1.04 & 1.89 & 0.82 & 0.13 & 0.25 & 0.63 & 0.49 & 0.53 & 0.54 & 1.28 \\
\hline $\mathrm{CD}$ at $5 \%$ & 3.02 & 3.47 & 2.36 & 0.38 & 0.73 & 1.83 & NS & 1.56 & 1.58 & 3.71 \\
\hline
\end{tabular}


Zinc fertilization@10 kg/ha significantly enhanced all the yield attributes and grain, straw and biological yields over the control. The increase in yield and yield attributes due to $\mathrm{Zn}$ fertilization might be the fact that $\mathrm{Zn}$ plays an important role in bio-synthesis of IAA and initiation of primordia for reproductive parts were reported by Mishra et al., (2001).

On the basis of the results it could be concluded that a combination of $50 \mathrm{~kg} \mathrm{P}_{2} \mathrm{O}_{5}$ $20 \mathrm{~kg} \mathrm{~S}$ and $10 \mathrm{~kg} \mathrm{Zn} \mathrm{ha}^{-1}$ proved to be most effective for improving the growth, yield attributes and yield of wheat.

\section{References}

Chaudhary, P. D.; Jat, R. S. And Sharma, H. S. (2003). Interaction effect of phosphorus, sulphur and PSB inoculation on growth, yield and nutrient uptake of wheat. Annals of Agricultural Research; 24(1):12-16.

Choudary N.R. Vyas, A.K., Singh, A.K. (1997). Growth and nutrient uptake in wheat as influenced by nitrogen. Phosphorus and Zinc fertilization Annals of Agricultural Res. 18: 365-366.

Dwivedi, S.K.; Meshram, M.R. and Pandey, N. (2014). Response of customized fertilizer on wheat (Triticum aestivum) under Chhattisgarh condition. The Bioscan, 9(4): 1509-1512.

Hrivna, L.; Kotkova, B. and Buresova, I. (2015). Effect of sulphur fertilization on yield and quality of wheat grain. Food Science and Technology Abstracts Cereal Research Communications. 43
(2): 344-352.

Inamullah Naeem Ali (2014). Assessment of various humic acid and sulphur levels for higher yields in wheat (Triticum aestivum L.). Sarhad Journal of Agriculture; 30(1):47-52.

Karimi, N.; Pormehr, M. and Ghasempour H. R. (2015). Interactive effects of arsenic and phosphorus on their uptake by wheat varieties with different arsenic and phosphorus soil treatments. International Academy of Ecology and Environmental Sciences, 5(1): 25-37.

Mishra, B.; Singh, R.K. and Senadhira, D. (2001). Recent advances and future strategies for breeding salt tolerant rice varieties. Rice research for food security and poverty alleviation Proceedings of the International-Rice-Research Conference, Los-Banos, Philippines, 31 March to 3 April, 2000:275-284.

Mumtaz, M.Z.; Aslam, M.; Jamil, M. and Ahmad, M. (2014). Effect of different phosphorus levels on growth and yield of wheat under water stress conditions. J. Environ. And Earth Sci.19 (4): 23-30.

Noonari, S.; Kalhoro, S.A.; Ali, A.; Mahar, A.; Raza, A.; Ahmed, M.; Shah, S.F.A. and Baloch, S.U. (2016). Effect of Different Levels of Phosphorus and Method of Application on the Growth and Yield of Wheat. Natural Science, 8: 305-314.

Singh, G.; Singh, R.; and Purushottam, K. (1996). Response of wheat (Triticum aestivum) to nitrogen, phosphorus and potassium fertilizer. Indian J. Agron., 40(1): 157-159.

\section{How to cite this article:}

Sandeep Kumar Yadav, Ghanshyam Singh, Rajeev Kumar, Pradeep Kumar and Brij Mohan. 2017. Effect of Phosphorus, Sulphur and Zinc on Growth, Yield and Yield Attributes of Wheat (Triticumaestivum). Int.J.Curr.Microbiol.App.Sci. 6(8): 2581-2584.

doi: https://doi.org/10.20546/ijcmas.2017.608.306 